\title{
NATURAL AND UNNATURAL PATHS
}

\author{
Gary Coyne \\ Department of Sociology \\ University of California, Riverside \\ Garycoyne1@gmail.com
}

Adam Smith in Beijing is Giovanni Arrighi's attempt to make sense of the rise of China and the fate of the neo-conservative Project for a New American Century, while at the same time speculating about the role of East Asia in the twenty-first century. In interpreting these current events Arrighi draws much from The Wealth of Nations, Adam Smith classic of politicaleconomy which proves to be surprisingly relevant despite being over two-hundred years old. One of the book's unifying themes is Adam Smith's prediction that one day "the inhabitants of all the different quarters of the world may arrive at that equality of courage and force, which by inspiring mutual fear, can alone overawe the injustice of independent nations into some sort of respect for the rights of one another” (p. 3).

Arrighi begins with a theoretical background for his argument by examining Smith, Marx, Schumpeter and other key thinkers on political-economy. Arrighi then spends the better part of his work sketching out the ups and downs of American hegemony in political and economic terms in the post-WWII world order while grounding this in the long-term historical narrative of the rise of the West and the basic logic of capitalism and how these processes worked (or not) in East Asia. Arrighi then considers China's economic growth, and is fairly successful in framing it in the terms provided by Adam Smith. Some space is also devoted to outlining the more obvious options for the twenty-first century. I will deviate slightly from Arrighi's interpretation of the role of the state in economic development to add some thoughts on the interconnections between the state, domestic policing, and economic growth. The book brings together several different strands of thought and firmly grounds the emergence of China in both historical and theoretical contexts, although like other books that attempt to synthesize such large amounts of information, the narrative does get bogged down with details at points.

The first section offers a reading of Adam Smith that is sharply at odds with the reading favored in neo-liberal circles which argues that Smith was an advocate for self-regulating markets and capitalism as an engine of "endless economic expansion" (p. 42). Much of Smith's purpose in writing The Wealth of Nations was to advise political actors how to structure the market to the advantage of labor and how to protect society in general from the interests of large businesses. In fact, Smith is not even entirely positive about the division of labor in his often-cited pin factory because the technical division of labor within a single unit of production leads to the creation of jobs that are both too simple and overly repetitive. Arrighi further argues that Smith would have labeled the industrial revolution an "unnatural" path of development because it privileged the role of industry and long distance trade over the development of the domestic market, and agriculture in particular. On the other hand, "China is repeatedly mentioned as the exemplar of a country that had followed the path to economic maturity that Smith calls 'the natural course of things'” (Arrighi 2007: 57). While Arrighi leaves it until the final section to fill in the details of this "natural path" he does invoke Sugihara's work to equate this path with the "industrious

Copyright $@$ 2009, American Sociological Association, Volume XV, Number 2, Pages 228-232 ISSN 1076-156X 


\section{JOURNAL OF WORLD-SYSTEMS RESEARCH}

revolution," or a type of economic growth that uses labor-intensive technologies embedded in flexible relations of production and ultimately raises standards of living while using fewer inputs of resources and capital. The "unnatural path," on the other hand, is equated with the industrial revolution, or capital-intensive production that uses large amounts of resources and relatively little labor. Arrighi later calls on Schumpeter's idea of creative destruction- in which social relations are continuously remade to realize structures with greater potential for production- to characterize the unnatural path. It should be noted here that Smith claims that his "unnatural" path entails a much greater potential for developing military power and thus places those societies following the "natural path" at a military disadvantage relative to those following the unnatural path.

The second section is largely historical and focuses on turbulence in the system of global finance. Arrighi argues that the United States had tremendous advantages in development because of its size and relative isolation. Furthermore, its domestic market was only partially integrated into the global market, and thus made large vertically integrated firms profitable -- railroads are an archetypal example. Much of this section, however, is organized by drawing parallels between economic downturns in the late nineteenth (Great Britain) and twentieth (US) centuries. Arrighi states that

[w] hat has occurred thus far is the tendency for uneven development in Brenner's sense to generate a long boom, followed by a long period of intensifying competition, reduced profitability, and comparative stagnation; itself followed by an upturn of profitability, based on a financial expansion centered on the epoch's leading economy (p. 118).

While each of these downturns signals the end of the leading nation's hegemony, there are also major differences. The massive national debt of the US has turned it into a sink for capital, while Great Britain became a major creditor. The near monopoly of military power by the US at present is another significant difference between these two downturns. This economic downturn has also seen marked trends away from the large vertically integrated firms that rely on the technical division of labor within units of production, as production is moving increasingly towards more fluid models in which smaller firms are linked via networks. In other words, Arrighi provides evidence that validates Smith's ideas on the division of labor.

The third section is also largely historical and examines the unraveling of United States hegemony and its attempts to extend hegemony - the "Project for a New American Century." Arrighi introduces the idea of "fixes of capital," meaning both the physical embedding of capital in infrastructure and capital goods, as well as a more metaphorical sense in that capital is always in search of larger profits. In this light "the new imperialism will appear as the outcome of a protracted historical process consisting of spatial fixes of increasing scale and scope, on the one hand, and, on the other, of a US attempt to bring this process to an end through the formation of a US-centered world government" (p. 228). Arrighi stresses that each successive hegemon was larger than the previous. This vindicates Smith's observation that the size of a market directly shapes the level of development. Arrighi goes on to shows that for two to three decades after WWII US military power was generally accepted as legitimate by other nations as it was actually offering protection from the USSR at a low cost. However, the Iraq debacle is understood in the context of using cheap oil from West Asia to help cement a world order centered on the US. In this light US military power now seems much more like a protection racket: it is both expensive and offered against dangers that the United States created, or helped to create. 
It is at this point that Arrighi takes a slight detour to examine the nature of militarily power, as much of the profitability of historic capitalism in the nineteenth century was premised on the forced expansion on the geographic area that was organized under its logic, that is, colonialism and imperialism. Drawing on correspondence between Marx and Engels, Arrighi points out that war making began a long trend toward commercialization when certain Italian city-states began to hire mercenaries. If this commercialization of warfare was found in a society on the unnatural path of development, as it would seem it inevitably would be military power would be increased by the technical division of labor as increasing numbers of functions could be taken on by a given army. Although the integration of such units could be problematic, the strict discipline needed to accomplish this amounted to the principles of "scientific management" applied to warfare. A further feature of such unnatural military development would be the application of capital intensive machinery to warfare, both for the creation of armaments for soldiers (i.e. mass produced rifles) and machines of war (i.e. armored steam ships) as well as for the provision of other military needs like transportation (i.e. railroads) and communication (i.e. the telegraph). Indeed if a state played its cards right, this type of war making activity could even pay for itself by opening access to new pools of resources that would stimulate further economic activity and then by increased tax revenues.

From here Arrighi outlines a number of the more plausible options for dealing with the rise of China in a political-military context. The first would look something like a new Cold War in which China could be first contained by, and later integrated into a series of security agreements in the same way that NATO was used to control and later integrate Russia. The second option would be to acknowledge the inevitability of China's accent and simply accommodate this and avoid open conflict. In fact, the Chinese government has itself espoused a policy of "emerging in a peaceful way" (p. 291). The third option would be a version of "playing the ends against the middle" as the countries of the Pacific rim could be drawn into a series of bilateral agreements that privileged the US position vis-à-vis other actors. Arrighi acknowledges that there would be no reason why other countries should allow themselves to be played against each other in this way. The US is not pursuing one of these policies because there is no widespread agreement on what it and its various segments of its population (working class or business leaders) would to gain or lose by the rise of China. Arrighi is clear however that the main reason there has yet to be a coherent response to China is that the United States has allowed itself to become distracted in Iraq. Whatever the final outcome in Iraq, China will likely be the ultimate winner of the "war on terror."

In explaining the rise of China Arrighi provides a fairly rich historical context from the Song dynasty down to the post Deng Xiaoping reforms. In the era before intensive contact with the societies of Europe and North America, East Asia was characterized by an interstate systemlike the one that developed in Western Europe- in which a common cultural heritage of the societies involved provided a framework for integration. However, this state system was centered on the comparatively much larger state of China, in a way that has no European parallel. Another major difference was the low level of conflict, both between the various state elements and by the elements collectively or individually in the expansion of the basic logic through space. Arrighi maintains that China's expansion into Inner Asia was not a primarily a grab for resources or markets comparable to colonialism and/or imperialism, but rather describes it as "the transformation of a hard-to-defend frontier into a pacified periphery and a buffer against raiders and conquerors from Inner Asia" (p. 317). The Qing Dynasty (1644-1911) attempted to counter 


\section{JOURNAL OF WORLD-SYSTEMS RESEARCH}

uneven economic development, both in space and in time. The "outcome of these policies was the remarkable peace, prosperity, and demographic growth which made eighteenth-century China an exemplar of Smith's 'natural' path to opulence" (p. 328). All this was thrown into disorder with the arrival of Western powers and the effective displacement of China as the regional hegemon. The foreign powers showed considerably less interest in Japan, and for that reason Japan was able to modernize and industrialize more or less on its own terms, and was eventually able to replace Britain as the regional leader East Asia. This was not to last, however, as China ended the seclusion of the early Communist period and ties with the outside and, more importantly, economic growth began to increase rapidly. It is the way in which this economic reorganization and growth occurred that led Arrighi to conclude the ultimate vindication of Smith is to be found in China.

In remaking the economy in the late 1970s and 1980s Deng Xiaoping and other leaders in Beijing focused first on the domestic market, with some of the first reforms focused on the agrarian sector. Here the role of the small but numerous township and village enterprises (TVEs) was key as they allowed for a gradual transition from agriculture to industrial labor by providing access to wage labor (generally in light industry) in ways that did not require a sudden and complete exit from existing economic structures. Central regulations also stipulated that the profits from these TVEs be retained at the local level and invested in infrastructure and education. Thus, they provided revenues to the places that typically fall behind urban areas as countries develop. Indeed, levels of literacy and numbers of college graduates in China compare very favorably to other countries with similar levels of per capita income. It is precisely this welleducated and well-trained workforce that allows Chinese entrepreneurs to replace capitalintensive machinery with highly skilled and self-directing labor. Organizing intensive labor in flexible ways like this is exactly what distinguishes the "industrious revolution" from its industrial counterpart. Furthermore, organizing labor in this way means minimizing the technical division of labor within units. A procedure Adam Smith would no doubt applaud.

It is when the role of the state in development is considered that Arrighi's analysis falls short, as there are significant parallels between domestic policing and the role of military power considered above. The Chinese state is currently in the implementation stages of a project called "Operation Golden Shield," which attempts to cover urban spaces with closed circuit television cameras, link them to some central location. There they could scan the feeds with facial recognition software and connect individuals to many of personal information such as police reports, work histories, medical history, education records, and even credit scores (Bradsher 2007). Most of the production of the needed cameras and infrastructures is being carried out in China, but companies in the United States are involved the development of the needed software. While the United States has increased its legal and technological capacities for monitoring its citizens after 9/11, China has the type of authoritarian government that is willing to go much further in the name of security and, perhaps more importantly, it is the sheer size of the Chinese population that makes the implementation of such projects massively profitable. Indeed the companies involved in Operation Golden Shield have raised the needed capital in America, with at least one of them being listed on the New York Stock exchange (Spencer 2007). While this may seem like something of a detour, the connections to the core of Arrighi's argument are both numerous and disquieting.

First this seems to suggest that it is possible to expand the logic capitalism into various social spaces as never before. Closed circuit television cameras systems are being used in factories and 
other places of employment because the close supervision of labor can raise productivity and minimize lost time and materials. The policing of consumption in places like shopping malls has increased the profitability in much the same way (Koskela 2000). Many of the places where cameras are being installed are not unfamiliar to capitalism, but scale is. Furthermore these infrastructures can be thought of as physically fixing capital in space, and to the extent that it is lucrative- the global market for homeland security is estimated at $\$ 200$ billion- this also opens up the possibility of the massive profits (Klein 2007). In fact, Shenzhen is both the one place where such an infrastructure is running and is one of the most profitable places to do business in China (Klein 2007). While the United States has much stronger commitments to civil liberties, these rights are in a state of flux in post-9/11 America and the use of close-circuit television networks is certainly on the rise. It does not seem to be much of stretch to point out that this may be a reshaping of social structures in ways that realizes an increased profit potential; that is to say this maybe a the process of creative destruction in action. The ways in which video surveillance changes the dynamics of social space has been examined elsewhere (Koskela 2000). The extent to which this system can provide a mechanism for self-sustaining profitability remains to be seen, but the parallels to the system of militarily enforced capitalist expansion discussed above are both significant and troubling.

It is in this light that we come to Arrighi's conclusions. He predicts that the two paths to development- the "industrious" and "industrial"- will eventually converge because, at least in part, the industrious path's modest use of resources is the only way that sustained economic growth would be possible for the six billion inhabitants of the world. While the Chinese path to growth is best described as the industrious path, the recent developments in its security apparatus suggests that China may be moving toward the Western pattern more quickly than the West is doing the reverse. Indeed, in the specific case of Operation Golden Shield there appears to be some synergy across the Pacific. East and West are now more closely intertwined than ever before and rapidly becoming more so. Here again we see Smith's views vindicated as Arrighi concludes that the conditions are now more favorable than ever before for the coming into existence of "the commonwealth of civilizations that Smith envisioned long ago" (p. 384). While we should not critique Arrighi too harshly for not including the rise of Chinese security apparatus in his analysis, it is evidence that he and Smith may be overly optimistic in predicting a commonwealth of civilizations based on nations respecting the rights of all.

\section{REFERENCES}

Arrighi, Giovanni. 2007. Adam Smith in Beijing: Lineages of the Twenty-First Century. New York: Verso.

Bradsher, Keith. 2007. “An Opportunity for Wall Street in China’s Surveillance Boom.” The New York Times, September 11, 2007.

Klein, Naomi. 2008. “China’s All Seeing Eye.” Rolling Stone, issue 1053.

Koskela, Hille. 2000. "The Gaze without Eyes: Video-Surveillance and the Changing Nature of Urban Space.” Progress in Human Geography 24(2):243-265.

Spencer, Richard. 2007. “China Launches 'Big Brother' to Control Workers.” The Daily Telegraph, August 16, 2007. 